\title{
Identification and determination of ascorbic acid, free organic acids and tannic substances in the grass of Inula L. genus species
}

\author{
Olena Yerenko, Galina Smoylovska and Taya Khortetska \\ Zaporizhzhya State Medical University, Zaporizhzhya, 69035, Mayakovskiy avenue, 26, \\ Ukraine
}

\section{profesor8707@gmail.com}

Keywords: Inula britannica L., Inula helenium L., paper chromatography, thin-layer chromatography, vitamin $C$, free organic acids, tannic substances.

The level of studying of Inula L. genus species, growing on the territory of Ukraine, is insufficient today. The study of chemical composition, accumulation of biologically active substances, pharmacological action of investigated grass species' extracts of Inula L. genus of Ukrainian flora are of current interest. The aim of the work is making qualitative and comparative analysis of ascorbic, organic acids and tannic substances content in the raw material of investigated species of Inula L. genus (Inula britannica L. and Inula helenium L.). Quantitative determination was carried out by volume titration method. The presence of ascorbic acid, organic acids and tannic substances in the raw material of Inula L. genus investigated species was established with the help of paper chromatography and thin-layer chromatography methods. The quantitative determination of total organic acids was carried out according to XI edition of State Pharmacopoeia methods in terms of malic acid. Water extracts were studied for the tannins presence in raw material of Inula L. genus investigated species. Compounds identification was carried out through chemical reactions in accordance with Ukrainian State Pharmacopeia. The results obtained showed the perspective of further study of the biological activity of Inula britannica L. and Inula helenium L.

\section{Introduction}

The Inula L. genus of the Asteraceae family contains over 200 species, more than 30 of which sprout in Ukrainian flora. Of all 30 species of Inula L. genus, growing on the territory of Ukraine, the Inula helenium L. is the only one used in official Ukrainian medicine. But during the harvesting phytogenetically close species are constantly found: I. britannica L., I. oculus - Christi L., I. germanica L., I. salicina L., I. aspera Poir., I. sabuletorum Czern. ex Lavr., I. vulgaris Lam., I. thapsoides Bieb. ex Willd. Spreng., I. ensifolia L. and I. macrophylla Kar. et Kir. The plants are most often found and reproduce their thickets in Zaporizhzhya, Dnipro, 
Donetsk, Vinnytsya, Khmelnytskiy, Odessa, acid quantitative content.

Ternopil and Chernivtsi regions $[1,2]$.

The representatives of Inula L. genus are perspective phytotherapy objects, which are traditionally used in scientific medicine and ethnoscience of many countries as expectorants during respiratory diseases, as diuretic, choleretic, anthelmintic and gall-forming agents. Thereby, the species containing a lot of biologically active compounds that have antiphlogistic, gastroprotective, antioxidant effects, are of particular interest now, namely Inula helenium L., Inula britannica L. [3, 4, 5, 6, $7,8]$.

The purpose of this work is making qualitative and comparative analysis of ascorbic, organic acids and tannic substances content in the raw material of investigated species of Inula L. genus (Inula britannica L. and Inula helenium L.).

One of the most important physiological functions of ascorbic acid and free organic acids is the ability to regenerate the tissues and to normalize capillary permeability through collagen and procolagen synthesis. Their participation in blood coagulation mechanisms is of particular importance since the activity of platelets, prothrombin complex and thromboplastin depends on their presence. Scientific sources confirm vitamin C presence in raw material of many plant species. However, there is almost no information about ascorbic
Ascorbic acid is a well-known, vital natural substance belonging to the derivatives of polyoxy- $\gamma$-lactones of unsaturated carbon acids. The human body is not able to synthesize this compound, it comes from the outside only, mainly with food products of raw origin or herbal agents. Vitamin $\mathrm{C}$ is directly involved in regulating oxidative-restorative processes occurring in living organisms, in carbohydrate metabolism (through the tryptophan synthesis), the formation of human steroid hormones, and strengthening of the liver detoxification function. The leading role of ascorbic acid in antioxidant protection of living organisms is established. Ascorbic acid and free organic acids are necessary for the human body to regulate oxidative-restorative biochemical reactions, carbohydrate metabolism (tryptophan synthesis), the steroid hormones formation, and the liver detoxification activity improvement $[9,10]$.

Organic acids form a large group of biologically active substances, but only a small amount of them is used in medical practice. It is well-known in literature that organic acids are characterised by antioxidant, adaptogenic, antiseptic and immunostimulating activities. Organic acids are the most common compounds in plants along with carbohydrates. They are intermediate products of oxidation of carbohydrates, fats, amino acids and proteins, and they are also used in amino acids, alkaloids, steroids synthesis and, thus, they are a binding 
link between carbohydrates, fats and proteins metabolism [11].

Tanning substances (tannins) include raw compounds having molecular weight 500 - 3000 $\mathrm{g} / \mathrm{mol}$, which are capable to reproduce strong bonds with proteins and alkaloids and which have tannic properties. As a rule, these are natural polyphenolic compounds that are brownish-yellow or colourless, the macromolecular ones of which have amorphous structure, and low-molecular ones have crystalline structure. Tanning substances are astringent, well soluble in water, acetone, ethanol, ethyl acetate and are practically insoluble in petroleum ether, benzene and chloroform. Many plants in nature contain tannins (especially dicotyledons). They are commonly met in the following families: pines, perennials, buckwheat, heather, beech, sumac, myrtle, rose, bean and aster. Tannins can be accumulated both in the underground and the aerial plant organs, mainly in cellular juice in free and bound state. In leaves tannins are present in epidermis and parenchyma cells, which surround conductive bundles and veins; in rhizomes and roots they are accumulated in crust parenchyma and medullary bundles. They are absent in mechanical tissues. As a rule, tannins are met in vacuoles of raw cells, they take active part in redox reactions. Then they pass to the cytoplasm and turn into brown or red amorphous substances, the so-called phlobaphenes, which have bactericidal and antifungal properties. They are partially deposited as spare nutrients and are used by raw cells in spring.

The tannins content in plants depends on their age, vegetation phase, growth location, climatic, genetic factors and soil conditions. The hydrolyzing tannins biosynthesis passes through the Shikimat way, the condensed tannins biosynthesis passes through a joint way (Shikimat and acetic). Medicinal plants and phytopreparations, containing tannins, have astringent, antiphlogistic, antibacterial, hemostatic and P-vitamin actions. They are used inwardly in case of intoxication by heavy metal salts, alkaloids, during chronic and incisive gastritis, colitis, enteritis and stomach bleedings. The tannins' hemostatic action is explained by formation of a special film on mucous protein membranes, which can prevent bleeding. In the form of rinsing tannins are also used for treating inflammatory processes of the throat, oral cavity and nose; in the form of rinsing, lubrications or irrigations tannins are used in case of bedsores, burns and abscesses [12].

The literature sources investigated indicate the presence and accumulation of ascorbic, free organic acids and tannic substances in the grass of many species of Inula L genus. However, the quantitative content of substances and their accumulation during vegetation are not established. 


\section{Experimental part}

Material and methods

Plants material

Inula britannica L., Inula helenium L., were collected on the territory of Ukraine.

Identification of ascorbic acid

Water extracts were rejected for the method: herb plants $(10.0 \mathrm{~g})$ were crushed to parts with a diameter of $1-2 \mathrm{~mm}$, added $100 \mathrm{~mL}$ of distilled water. It was performed using Soxhlet apparatus for $1 \mathrm{~h}$ for all the solvents. Re-extract was performed with new portions of solvent. The cooled extracts were filtered through cotton wool and under vacuum evaporated.

Ascorbic acid identification in raw material of investigated species of Inula L. genus was carried out by thin-layer chromatography method in the system acetic acid $15 \%$, with the subsequent drying on air and processing with the help of $0.04 \%$ water solution of sodium 2,6 dichlorophenolindophenolate [13].

Quantitative determination of ascorbic acid

Quantitative determination was carried out by volume titration method. For this purpose, air-dried herb plants $(10.0 \mathrm{~g})$ were thoroughly pound in a mortar, gradually adding distilled water $(300 \mathrm{~mL})$, decocting for 10 minutes and filtering. The extract $(1 \mathrm{~mL})$ was poured into a $100 \mathrm{~mL}$ titration flask, a solution of hydrochloric acid $(1 \mathrm{~mL}$ of $2 \%)$ and distilled water $(13 \mathrm{~mL})$ were added. The mixture was titrated against 2,6- dichloro-sodiumphenolindophenolate solution $(0.04 \%)$ up to a faint pink coloration, stable for 1 $\min$.

$1 \mathrm{~mL}$ of $0.04 \%$ 2,6-dichlorosodiumphenolindophenolate solution corresponds to $0.000088 \mathrm{~g}$ of ascorbic acid.

The ascorbic acid content (\%) in the grass of Inula L. genus species was calculated by the formula:

$$
X=\frac{V \cdot F \cdot 0,000088 \cdot V_{1} \cdot 100 \cdot 100}{m \cdot V_{2} \cdot(100-W)},
$$

$\mathrm{V}$ - the volume of titrated solution, $\mathrm{mL}$;

F - titrated solution concentration correction;

0,000088 - titre for ascorbic acid determination, $\mathrm{g}$;

$\mathrm{V}_{1}$ - volume of extraction for analysis, $\mathrm{mL}$;

$\mathrm{m}$ - herb weight, g;

$\mathrm{V}_{2}-$ volume of extraction for titration, $\mathrm{mL}$;

W - loss of material mass during the drying process, $\%$.

Identification of organic acids

The presence of organic acids in raw material of investigated species of Inula L. genus was established with the help of paper chromatography and thin-layer chromatography 
methods in system efir petroleum - acetic acid water (13:3:1) using compounds of working reference substances (Ascorbic acid SigmaAldrich (Germany)).

Quantitative determination of total organic acids

The quantitative determination of total organic acids was carried out according to XI edition of State Pharmacopoeia methods in terms of malic acid (Malic Acid DL (China)) [14].

For this purpose, chopped $(\mathrm{d}=2 \mathrm{~mm})$ raw material $(25 \mathrm{~g})$ were put into a $250 \mathrm{~mL}$ flask, distilled water $(200 \mathrm{~mL})$ was added and heated for 2 hours on a boiling water bath. The system was cooled, poored into a $250 \mathrm{~mL}$ volumetric flask, the volume was brought up to mark with distilled water and thoroughly mixed. The extract $(10 \mathrm{~mL})$ thus obtained was put into a $500 \mathrm{~mL}$ titration flask, $200 \mathrm{~mL}$ of freshly boiled distilled water was added, as well as $1 \mathrm{~mL}$ of $1 \%$ phenolphthalein alcohol solution, and $2 \mathrm{~mL}$ of $0.1 \%$ blue methylene solution. The mixture was titrated against $0.1 \mathrm{~m}$ sodium hydroxide solution up to purple-red coloration.

The content of free organic acids sum in raw material $(\%)$ in terms of malic acid was calculated by the following formula:

$$
\begin{aligned}
& X=\frac{V \cdot 0.0067 \cdot 250 \cdot 100 \cdot 100}{m \cdot 10 \cdot(100-W)} \\
& \text { V - volume of titrant solution, } \mathrm{mL} ; \\
& 0.0067 \text { - malic acid solution titer; }
\end{aligned}
$$

$\mathrm{m}$ - mass of investigated raw material, g;

W - humidity of investigated raw material, $\%$.

In order to eliminate impact on accuracy during ascorbic acid determination, the concentrations of this substance (titration with 2,6-dichloro-sodiumphenolindophenolate

solution) were taken into account in calculations.

Determination of tannins

Water extracts were studied for the tannins presence in raw material of Inula L. genus investigated species. Compounds identification was carried out through chemical reactions in accordance with Ukrainian State Pharmacopeia.

In order to obtain reliable tannins identification in the grass of studied species, paper chromatography and thin-layer chromatography methods were carried out on plates "Silufol UV-254" in systems n-butanol acetic acid - water (4:1:5), ethyl acetate - acetic acid - water (10:2:3), n-butanol - acetic acid water $(4: 1: 2)$, followed by treatment of air-dried chromatograms with the help of a $3 \%$ solution of iron (III) chloride. The bluish-gray spots (catechins) were observed.

The quantitative tannins content in raw material was carried out according to the XI edition of State Pharmacopoeia methods. About $2.0 \mathrm{~g}$ (precise weighting) of thoroughly crushed samples sifted through a sieve $(\mathrm{d}=3 \mathrm{~mm})$ were 
placed into a $500 \mathrm{~mL}$ flask, then $250 \mathrm{~mL}$ of distilled and boiling distilled water was added; and boiled on a boiling water heater for 30 minutes under constant stirring. After that the extract was cooled to the temperature $25-27^{\circ} \mathrm{C}$, about $200 \mathrm{~mL}$ of it was filtered into a conical flask of $200 \mathrm{~mL}$ capacity. For the quantitative analysis, $25 \mathrm{~mL}$ of aqueous extract were taken with the help of pipette and transferred into a 750 $\mathrm{mL}$ flask, $500 \mathrm{~mL}$ of distilled water were added, as well as $25 \mathrm{~mL}$ of indigosulfonic acid solution. Titration was carried out under thorough mixing and with the help of a $0.02 \mathrm{M}$ potassium permanganate solution until golden-yellow colour appearance.

A control experiment was conducted in parallel. The titre of $0.02 \mathrm{M}$ potassium permanganate solution is equal to 0.004157 in terms of tannin substance. The tannin substances quantitative content (\%) was calculated by the following formula:

$$
\mathrm{X}=\frac{\left(V-V_{1}\right) \cdot 0,004157 \cdot 250 \cdot 100 \cdot 100}{m \cdot 25 \cdot(100-W)}
$$

$\mathrm{V}$ - volume of titrant spent on extract titration, $\mathrm{mL}$;

$\mathrm{V}_{1}$ - volume of titrant solution spent on check experiment titration, $\mathrm{mL}$;

0.004157 - the tannins titre (in terms of tannin), g;
250 - total volume of obtained extract, $\mathrm{mL}$

$\mathrm{m}$ - grass weight, $\mathrm{g}$;

25 - extract volume for titration, $\mathrm{mL}$;

W - loss of primary products' mass during their drying, $\%$.

\section{Results and discussion}

The presence of ascorbic and free organic acids in the grass of investigated species of Inula L. was determined on the previous step using paper chromatography and thin-layer chromatography methods in systems acetic acid $15 \%$, efir petroleum - acetic acid - water (13:3:1) $[10,12]$. At the same time, the chromatography of working reference substances was carried out. In order to display the ascorbic acid spots, 0.001 $\mathrm{N}$ solution of 2,6-dichlorosodiumphenolindophenolate were used. During experiments and monitoring, the compound was observed in the form of white spots on a pink background $(\mathrm{Rf}=0.69)$. Organic acids were determined by fluorescence in UV rays. Wine $(R f=0.37)$, citric $(R f=0.46)$, acetic $(R f=0.49)$, propionic $(\mathrm{Rf}=0.52)$, cinnamic $(\mathrm{Rf}=0.55)$, myristic $(\mathrm{Rf}=0.58)$, palmitic $(\mathrm{Rf}=0.61)$, malic $(R f=0.64)$, benzoic $(R f=0.72)$, fumaric $(R f=$ $0.77)$ organic acids were identified [15]. 
Table 1. The content of ascorbic acid and total free organic acids in the grass Inula britannica L., Inula helenium L.

\begin{tabular}{|l|c|c|c|c|}
\hline \multirow{3}{*}{ Vegetation phase } & \multicolumn{2}{|c|}{$\begin{array}{r}\text { Inula britannica L., } \\
(\overline{\mathrm{x}} \pm \Delta \overline{\mathrm{x}}), \%, \mu=6\end{array}$} & \multicolumn{2}{|c|}{$\begin{array}{c}\text { Inula helenium } \mathrm{L} ., \\
(\overline{\mathrm{x}} \pm \Delta \overline{\mathrm{x}}), \%, \mu=6\end{array}$} \\
\cline { 2 - 5 } & $\begin{array}{c}\text { free organic } \\
\text { ascids }\end{array}$ & $\begin{array}{c}\text { ascorbic acid } \\
\text { free organic } \\
\text { acids }\end{array}$ \\
\hline Start of vegetation & $0.03 \pm 0.01$ & $0.01 \pm 0.001$ & $0.07 \pm 0.01$ & $0.01 \pm 0.001$ \\
\hline Mass vegetation & $0.48 \pm 005$ & $0.19 \pm 0.02$ & $0.43 \pm 0.03$ & $0.22 \pm 0.02$ \\
\hline Bud formation & $0.47 \pm 0.05$ & $0.18 \pm 0.02$ & $0.40 \pm 0.04$ & $0.21 \pm 0.02$ \\
\hline Start of flowering & $0.44 \pm 0.04$ & $0.15 \pm 0.01$ & $0.38 \pm 0.03$ & $0.18 \pm 0.02$ \\
\hline Mass flowering & $0.43 \pm 0.04$ & $0.12 \pm 0.01$ & $0.37 \pm 0.03$ & $0.15 \pm 0.01$ \\
\hline Fructification & $0.18 \pm 0.02$ & $0.10 \pm 0.01$ & $0.11 \pm 0.01$ & $0.11 \pm 0.01$ \\
\hline
\end{tabular}

The obtained results of investigations are given in table 1. Analysis of the results shows that accumulation of ascorbic and free organic acids in Inula britannica L. and Inula helenium L. grass during the entire period of vegetation was rather close among investigated species and differed insignificantly, which confirms high phylogenetic propinquity of investigated plants.

Maximum substances accumulation was observed during the period of mass vegetation and bud formation. Thus, the concentration of ascorbic acid in Inula britannica L. grass was established equal up to $0.48 \pm 0.05 \%$ and $0.47 \pm$ $0.05 \%$; and in Inula helenium L. grass - up to $0.43 \pm 0.03 \%$ and $0.40 \pm 0.04 \%$ correspondingly. At the same time, the content of free organic acids in Inula britannica L. grass was equal up to $0.19 \pm 0.02 \%$ and $0.18 \pm 0.02 \%$; and in Inula helenium L. grass up to $0.22 \pm$ $0.02 \%$ and $0.21 \pm 0.02 \%$. High concentrations of compounds in the investigated species' raw material persisted until the end of flowering period.

The ascorbic and free organic acids' content in the grass of investigated species during mass vegetation was quite close and for Inula britannica L. it was accordingly equal up to 0.48 $\pm 0.05 \%$ and $0.19 \pm 0.02 \%$; for I. helenium L. it was equal up to $0.43 \pm 0.03 \%$ and $0.22 \pm 0.02 \%$ ).

In order to segregate tannins, the investigated raw material was extracted with the help of hot water; then the extract was purified from the related compounds presence by successive action of ether petroleum benzene, followed by a mixture of benzene and chloroform (1:1) and, finally, by petroleum ether and ethyl acetate. The preliminary extraction of investigated raw material with the help of nonpolar or low polar organic solvents was used to separate chlorophyll, lipids and terpenoids. 
Then, extraction with the help of ethanol with purification by column chromatography on polyamide was performed with the purpose of tannins segregation.

Catechins were detected in the form of three pale blue spots $(\mathrm{Rf}=0.44,0.56$ and 0.73$)$. The chromatograms were dried, treated with iron (III) chloride solution, and a brownish-red stains colouring was observed. Catechin, catechin gallates and gall acid solutions $(+)$ were used as working reference substances.

It was found out that raw material of Inula L. genus investigated species contained the following compounds from condensed tannins class: $(+)$ catechin, catechin gallat.

The tannins concentration in raw material is determined by gravimetry, photometry, spectrophotometry and other methods.

We used the XI edition of State Pharmacopoeia methods. The obtained data is given in table 2 .

The data shown in table 2 allows concluding that tannins are accumulated in the grass of both Inula L. genus species.

Significant tannins concentrations in raw material of Inula L. genus investigated species are important in the development of hepatoprotective effect of lyophilic extracts' biologically active compounds complex. The tannins content in Inula helenium L. and Inula britannica L. grass during the flowering period was respectively equal to $9.30 \pm 0.92 \%$ and 8.62 $\pm 0.81 \%$.
Table 2. The content of tannic substances in the grass Inula britannica L., Inula helenium L.

\begin{tabular}{|l|c|c|}
\hline \multicolumn{1}{|c|}{$\begin{array}{c}\text { Vegetation } \\
\text { phase }\end{array}$} & $\begin{array}{c}\text { Inula } \\
\text { britannica } \\
\mathrm{L} ., \\
(\overline{\mathrm{x}} \pm \Delta \overline{\mathrm{x}}), \\
\%, \mu=6\end{array}$ & $\begin{array}{c}\text { Inula } \\
\text { helenium } \\
\mathrm{L} . \overline{\mathrm{x}} \pm \Delta \overline{\mathrm{x}}), \\
\%, \mu=6\end{array}$ \\
\hline $\begin{array}{l}\text { Start of } \\
\text { vegetation }\end{array}$ & $0,31 \pm 0,03$ & $0,40 \pm 0,04$ \\
\hline $\begin{array}{l}\text { Mass } \\
\text { vegetation }\end{array}$ & $0,59 \pm 0,06$ & $1,99 \pm 0,20$ \\
\hline Bud formation & $1,90 \pm 0,18$ & $2,98 \pm 0,30$ \\
\hline $\begin{array}{l}\text { Start } \\
\text { flowering }\end{array}$ & $6,40 \pm 0,61$ & $7,30 \pm 0,70$ \\
\hline Mass flowering & $8,62 \pm 0,81$ & $9,30 \pm 0,92$ \\
\hline Fructification & $4,30 \pm 0,42$ & $5,40 \pm 0,61$ \\
\hline
\end{tabular}

\section{Conclusions}

Thus, the Inula britannica L. and Inula helenium L. grass contained quite significant concentrations of ascorbic acid, free organic acids and tannic substances, which greatly influence the biological effect of herbal medicinal products made of raw material.

\section{Acknowledgements}

The study was carried out within Zaporizhzhya State Medical University research work: Pharmacognosy and ecological research of promising species of flora families of Ukraine for the purpose of standardization of plant raw materials and preparation of medicinal products. State registration number $0117 \mathrm{U} 006960$. 


\section{References}

[1] Mruthunjaya K., Hukkeri V. I. In vitro Antioxidant and free radical scavenging potential of Parkinsonia aculeate Linn. Pharmacognosy Magazine. 2008; 4(13):42-51. Available from: https://www.researchgate.net/publication/279899402_In_ vitro_antioxidant_and_free_radical_scavenging_potential _of_Parkinsonia_aculeata_Linn

[2] Samar Amin., Zahoor A Kaloo, Seema Singh, Tabinda Altaf. Medicinal importance of genus Inula - A Review. Int J Cur Rev. 2013 Jan;5(2):20-26.

[3] Chupahina G. N., Maslennikov P. V., Skryipnik L. N., Besserezhnova M. I. Reaktsiya pigmentnoy $i$ antioksidantnoy sistem rasteniy na zagryaznenie okruzhayuschey sredyi g. Kaliningrada vyibrosami avtotransporta. Vestnik Tomskogo gosudarstvennogo universiteta. Biologiya. 2012;2(18):171-185. Available from: http://journals.tsu.ru/uploads/import/757/files/18-171.pdf

[4] Seca Ana M. L., GrigoreAlice, Pinto Diana C.G.A., Silva Artur M.S. The genus Inula and their metabolites: From ethnopharmacological to medicinal uses. Journal of Ethnopharmacology. 2014;154(2):286310 . Available from:

https://doi.org/10.1016/j.jep.2014.04.010

[5] Mohan S, Gupta D. Phytochemical analysis and differential in vitro cytotoxicity assessment of root extracts of Inula racemosa. Biomed Pharmacother.2017 May;89:781-795. DOI: 10.1016/j.biopha.2017.02.053

[6] Kalachaveedu M., Raghavan D., Telapolu S., Kuruvilla S., Kedike B. Phytoestrogenic effect of Inula racemosa Hook f-a cardioprotective root drug in traditional medicine. J. Ethnopharmacol. 2017; 8: 408416. DOI: 10.1016/j.jep.2017.09.001

[7] Salim Hatim, Rimawi Waleed H., Mjahed Arwa. Analysis of Extracts From Palestinian Inula Viscosa for Their Phenolic, Flavonoid and Lipid Contents, Antioxidant, Antibacterial Activity. Journal of Chemistry and Biochemistry. 2017 June; 5(1):12-23. Available from: https://doi.org/10.15640/jcb.v5n1a2
[8] Kurkin V. A., Avdeeva E. V., Petruhina I. K. Aktualnyie aspektyi standartizatsii lekarstvennogo rastitelnogo syirya, soderjaschego antratsenproizvodnyie, $\mathrm{i}$ slabitelnyih preparatov na ih osnove. Fundamental'nye issledovaniya. 2015;2:1424-1431.

[9] Lubsandorzhieva P.B., Azhunova T.A., Cybanov K.C. Poluchenie ekstrakta suhogo iz 4komponentnogo sbora i soderjanie $\mathrm{v}$ nem biologicheski aktivnyih veschestv. Himiya rast. syr'ya. 2008;1:107-110.

[10] Spiridon Iuliana, Nechita Constantin Bogdan, Niculaua Marius, Silion Mihaela, Armatu Alice, Teacă Carmen-Alice, et al. Antioxidant and chemical properties of Inula helenium root extracts. Cent. Eur. J. Chem. 2013;11(10): 1699-1709. DOI: 10.2478/s11532013-0295-3

[11] Pupyikina K. A., Baschenko N. Zh., Makara N. S. Fitohimicheskoe izuchenie i antioksidantnyie svoystva nekotoryih rasteniy, introdutsirovannyih $\mathrm{v}$ Respublike Bashkortostan. Vesn. VGU. Ser.: Himiya. Biologiya. Farmatsiya. 2006;2:357-360.

[12] Yerenko O. K.. Farmakognostichne vivchennya vidiv rodu Inula $L$. floru Ukrainu ta otrimannya substancij na ih osnovi [dissertation]. L'viv: L'vivs'kij nacional'nij medichnij universitet imeni Danila Galic'kogo; 2013. 252 p.

[13] Gosudarstvennaya Farmakopeya SSSR: Vyp. 2: Obshchie metody analiza. Lekarstvennoe rastitel'noe syr'e. MZ SSSR. - 11 - e izd., dop.; M. : Medicina; 1987. $400 \mathrm{p}$.

[14] Sergunova E. V., Marahova A. I., Avrach A. S. Metodyi kolichestvennogo opredeleniya organicheskih kislot $\mathrm{v}$ lekarstvennom rastitelnom syire $\mathrm{i}$ vodnyih izvlecheniyah. Farmaciya. 2013;4:8-11.

[15] Vronska L. V., Demyd A. Ye., Ezhned M. A. Development of standardization methodology of elecampane rhizomes and roots (Inula helenium L.) for the hydroxycinnamic acids content. Farmatsevtichniy chasopis. 2016;2:26-31. Available from: http://nbuv.gov.ua/UJRN/Phch_2016_2_7 